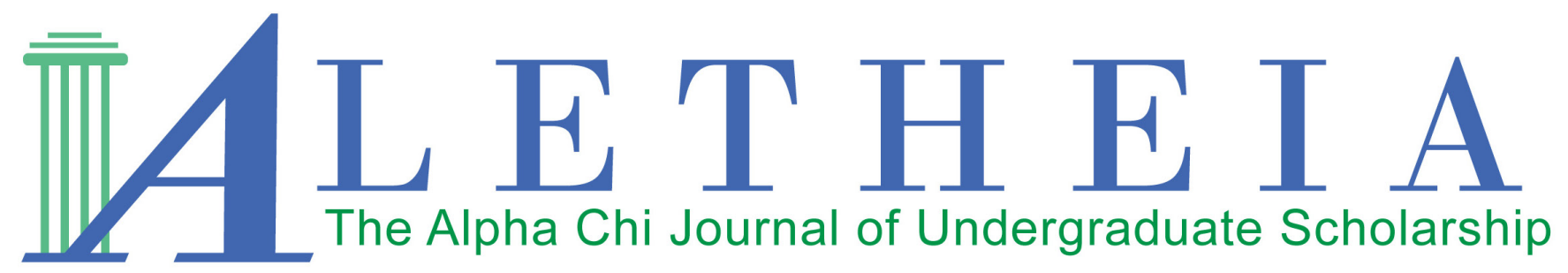

Volume 6 | Issue 2 | 2021

\title{
The Lawless Land of Social Media: \\ A Proposal of Synopticism as a Product of Panopticism
}

\author{
Emma East
}

\author{
Southeastern University \\ Florida Lambda Chapter
}

Vol. 6(2), 2021

Title: The Lawless Land of Social Media: A Proposal of Synopticism as a Product of Panopticism

DOI: $10.21081 / \mathrm{ax} 0293$

ISSN: 2381-800X

Keywords: panopticism, synopticism, Michel Foucault, Thomas Mathiesen, technological dependency This work is licensed under a Creative Commons Attribution 4.0 International License.

Author contact information is available from tlindblom@alphachihonor.org or kvosevich@alphachihonor.org

\section{Aletheia-The Alpha Chi Journal of Undergraduate Scholarship}

- This publication is an online, peer-reviewed, interdisciplinary undergraduate journal, whose mission is to promote high quality research and scholarship among undergraduates by showcasing exemplary work.

- Submissions can be in any basic or applied field of study, including the physical and life sciences, the social sciences, the humanities, education, engineering, and the arts.

- Publication in Aletheia will recognize students who excel academically and foster mentor/mentee relationships between faculty and students.

- In keeping with the strong tradition of student involvement in all levels of Alpha Chi, the journal will also provide a forum for students to become actively involved in the writing, peer review, and publication process.

- More information can be found at www.alphachihonor.org/aletheia. Questions to the editors may be directed to tlindblom@alphachihonor.org or kvosevich@alphachihonor.org.

Alpha Chi National College Honor Society invites to membership juniors, seniors, and graduate students from all disciplines in the top ten percent of their classes. Active on nearly 300 campuses nationwide, chapters induct approximately 10,000 students annually. Since the Society's founding in 1922, Alpha Chi members have dedicated themselves to "making scholarship effective for good." Alpha Chi is a member in good standing of the Association of College Honor Societies, the only national accrediting body for collegiate honor societies. A college seeking a chapter must grant baccalaureate degrees, be regionally accredited, and be a not for profit institution. 


\title{
The Lawless Land of Social Media: A Proposal of Synopticism as a Product of Panopticism
}

\author{
Emma East \\ Southeastern University \\ Florida Lambda Chapter
}

\begin{abstract}
This article analyzes the theories of panopticism and synopticism and explores how these theories operate within technology, specifically social media. The paper provides an overview of panopticism's history - spanning from Jeremy Bentham to Michel Foucault to modern surveillance ethics - and summarizes the research of synopticism primarily focused on Thomas Mathiesen's work, "The Viewer Society Michel Foucault's 'Panopticon' Revisited." With this foundation in place, Mathiesen's claim that Panopticons and Synopticons are intertwined and thus coexist is challenged. Contrary to Mathiesen's claims, the primary proposal of this article is that synopticism is a product of panopticism, a view that has not been previously explored. A new term, illusory synopticism - the feeling that users engaging in social media are omnipotent, omniscient, and omnipresent and thus hold the power as many view the few-is used to explain how synopticism operates as a product of panopticism. A further explanation of this term reveals how illusory synopticism creates an environment in which technological users feel safe and in control, which, if left unchecked, could promote technological dependency and in extreme cases lead to technological addiction. Although scholars' opinions vary on social media's effects on individuals and society, their shared view is that social media is an active and growing branch of technology. Substantial documentation of technological addiction along with statistical evidence is offered to support these claims. The conclusion introduces both positive and negative effects of social media, along with methods to combat technological addiction both individually and collectively.
\end{abstract}

Keywords: panopticism, synopticism, Michel Foucault, Thomas Mathiesen, technological dependency 
Perceptions can be altered by things that are seen, said, or heard. Often, a combination of these three factors creates a compelling narrative that exists solely in an individual's mind. The increase of technological integration (specifically internet usage) can be supported with statistical evidence. For example, in December 1995, 16 million people used the internet; by March of 2002, that number grew to 5,168 million users (Internet Growth Statistics). With increasing technological integration in users' daily lives, technology now plays a role in perception and decision making. Social media platforms begin to form their own social structures. Philosophers such as Michel Foucault proposed theories that can now be applied to technology; however, as technology continues to advance, new philosophical theories begin to emerge, thus creating tension between past and present viewpoints. Thomas Mathiesen claims that panopticism and synopticism coexist due to increasing technological advancements and create a "viewer society in a two-way and double sense" (215). Panopticism and synopticism are not societal structures produced by technology but rather entities existing within virtual realms. The lack of research on virtual pan/syn-opticism requires new terminology to understand these concepts. The evolution of panopticism to virtual panopticism created a new power dynamic that is sustained by a new term, "illusory synopticism." Illusory synopticism claims that the feeling that social media users are omnipotent, omniscient, and omnipresent and thus hold the power as many view the few, fuels and strengthens virtual panopticons. The impact of virtual panopticism expressed through illusory synopticism provides a new that aids in understanding technological dependency.

\section{The History of the Panopticon and Synopticon}

English philosopher Jeremy Bentham doubtfully recognized his theories as prophetic when he outlined the now-famous Panopticon. Bentham described the structure of the Panopticon as "circular" with "the apartments of the prisoners occupy[ing] the circumferences," see image 1 (Bentham 225). Prisoners were "secluded from all communications with each other by partitions," and isolation was utilized as a means of control (Bentham 225). In the center stands a tower with stationed guards, leaving the inmates aware that at any moment punishment can descend (Felluga).

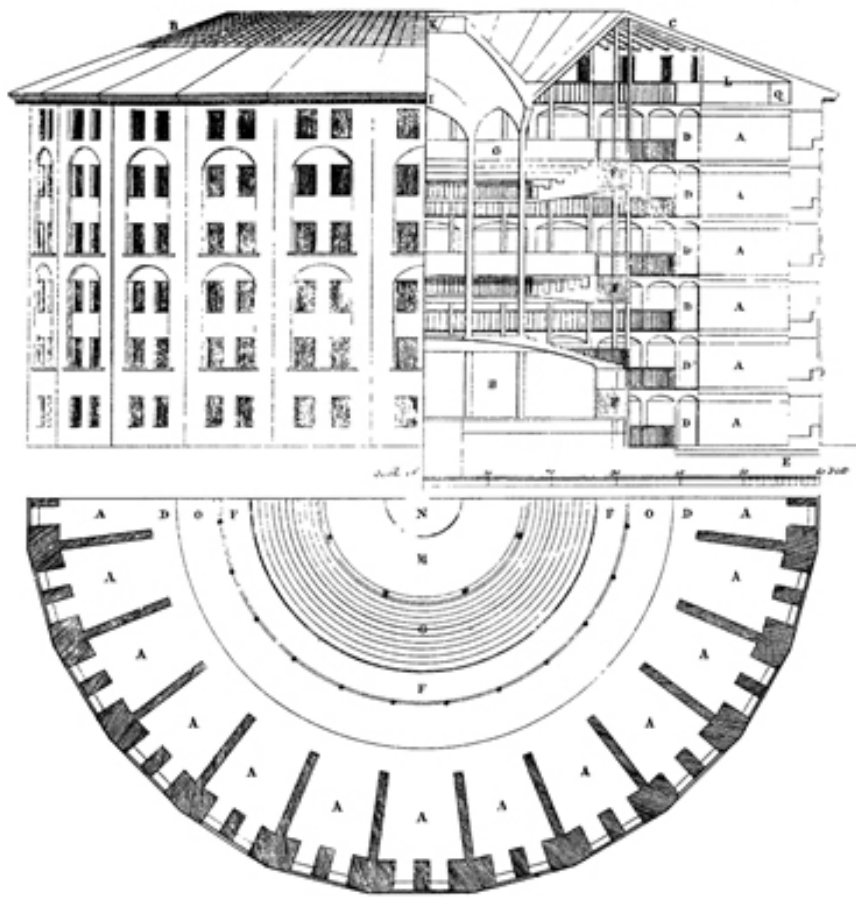

Image 1

Source: Bentham, Jeremy. Plan of the Panopticon, 1791, Wikimedia Commons, https://commons.wikimedia.org/ wiki/File:Panopticon.jpg

However, once the precedent of punishment is established, guards no longer need to remain in the tower. Inmates will not know whether a guard is surveilling, but the architectural structure of the Panopticon creates the illusion of constant surveillance; inmates maintain a sense of security by self-regulating their behavior based on internalized rules (Felluga). The cells are used for "all purposes: work, sleep meals, punishment, [and] devotion" (Bentham 225). Bentham's Panopticon's effects extend beyond the physical structure of a penitentiary house and into a psychological realm. Though the Panopticon is not a gruff, cold collection of cells - in fact, Bentham himself addresses the accusation that the Panopticon is too desirable in his letters - its atmosphere reeks of mental manipulation (Bentham 228). The intense mental and emotional challenges that Panopticons pose cannot be overlooked. Psychoanalyst Jacques-Alain Miller assesses that the Panopticon's "powers actually create an all-seeing, omnipresent, omniscient body that condemns the inhabitants to a dependency that no ordinary prison can emulate, a body that is very like some fabricated 
God" (Miller and Miller 4). The Millers further their critique of Bentham's Panopticon by saying, "The Panopticon is a machine that creates a semblance of God" (5). Foucault also agrees with the claim that the Panopticon "disindividualizes power," and he believes that "power somehow inheres in institutions themselves rather than in the individuals that make those institutions function" (Felluga). However, as Panopticons morph into Virtual Panopticons, the perspective of who truly holds the power shifts. The concept of illusory synopticism expounds on how the human desire for power aids in keeping the Panopticon functioning because it allows inmates to feel powerful despite their true powerlessness. A key factor in determining the Panopticon's relevancy to the present day is to consider the term itself: pan means all, and optic means seeing (Online Etymology Dictionary). The Panopticon utilizes architecture to allow a few individuals to control many. This seemingly all-seeing structure cannot be separated from current studies of surveillance, personal camera usage (such as cell phones), social media, security systems, etc.

Although many philosophical ideas remain confined to the pages of textbooks, the Panopticon continues to remain a relevant topic in academic communities. A prominent contributor to the Panopticon's relevancy, philosopher Michel Foucault, proposes that "The Panopticon...must be understood as a generalizable model of functioning; a way of defining power relations in terms of the everyday life of men" (205). He emphasizes that the Panopticon is not merely a prison; "it serves to reform prisoners, but also to treat patients, to instruct schoolchildren, to confine the insane, to supervise workers, to put beggars and idlers to work" (Foucault 205). Foucault's book, Discipline and Punish: The Birth of the Prison, expounds on Bentham's Panopticon along with supporting relevant theories. No longer viewed predominately as a penitentiary house, Foucault expediates the evolution of the Panopticon from a physical structure to a philosophical concept that continues to advance both in theory and as a critique of society. Foucault's adaptation of the Panopticon into everyday life opens the door for contributions from countless scholars. Literature from the discourse community reflects the growth of Foucault's Panopticon with a particular interest in the study of technological influences on this philosophical concept. Although Foucault crafted his theories of power, punishment, and discipline in a time with far less technology than the present, his pliable philosophies adapt as technological integration continues. To demonstrate what Brunon-Ernst calls "the impressive range of panoptical critical reinterpretation in the field of surveillance studies" (194), consider that current branches of panopticism research number more than twenty. ${ }^{1}$ Note that this research that stems from the Panopticon does not include branches of the panoptic that extend into education, literature, film, and religion; the list below is solely concerned with the branches of panopticism that extend from surveillance studies. Such a list is useful to demonstrate how meticulously panopticism can operate within a certain field, but the broad effects of panopticism cannot be properly understood through its limitations. The integration of technology into the Panoptic provides new areas of study that are built on the foundation of Foucault's theories. Since technology advances at a rapid pace, new areas for future study continuously arise.

In Western society, everyone is at risk of being locked up in a Panopticon, but many individuals may not realize they are in a cell; without intervention, Panopticons continue running efficiently because the inmates sustain the prison. Foucault himself believed that individuals are "in the panoptic machine" (205); this machine demands production, and the product aids in sustaining the machine. The Panopticon's self-sufficiency aids in growth. Foucault explains the incorporation of the Panoptic into society. He attests that "the panoptic schema, without disappearing as such or losing any of its properties, was destined to spread throughout the social body; its vocation was to become a generalized function" (207). Foucault's Panopticon results in seven different effects: the internalization of rules and regulations, rehabilitation rather than cruel and unusual punishment, surveillance into private aspects of individuals' lives, information society, bureaucracy, efficiency, and specialization (Felluga). With these effects in mind, the adaptation from Foucault's Panopticon into a Virtual Panopticon begins with surveillance theories. If "we extend 'the power of the gaze' to include all kinds of data collection and visual surveillance, we may immediately

\footnotetext{
${ }^{1}$ Brunon-Ernts lists "Ban-opticon, Cybernetic panopticon, Electronic panopticon, Fractal panopticon, Global panopticon, Industrial panopticon, Myopic panopticon, Neo-panopticon, Omnicon, Panoptic discourse, Panopticon-at-large, Panoptic sort, Panspectron, Pedagopticon, Polypticon, Postpanopticon, Social panopticism, Superpanopticon, Synopticon, Urban panopticon and so on" (194-195).
} 
see its relevance to the analysis of modern surveillance" (Manokha 234). Surveillance enhanced by technology raises concerning questions regarding virtual panopticism. For example, who is in control of the surveillance devices? How does technology affect Foucault's theory of gaze? Virtual panopticism manifests in multiple areas including but not limited to censorship, social media, and increasingly personalized data algorithms. The transition from Foucault's Panopticon to the rise of virtual panopticism is not clearly defined. Debates about which of Foucault's theories remain relevant versus how his philosophies must change with the times continue.

With the rapid expansion of panopticism comes a new "opposite process of great significance which has occurred simultaneously and at an equally accelerated rate" (Mathiesen 215). That process is called synopticism. Mathiesen claims that synopticism is exercised by "hundreds of millions of people at the same timewith great force to see and admire the few" (Mathiesen 215). In other words, panopticism is when few view the many whereas synopticism is when many view the few. Mathiesen describes three parallels between panopticism and synopticism; first, he claims "the acceleration which synopticism, as well as panopticism, has shown in modern times, that is, during the period 1800-2000" (219); second, he explains, "the panoptical surveillance structure and the media structure are parallel in that they are archaic, or 'ancient', as means or potential mean of power in society" (222). Third, the most relevant assertion needed to distinguish the roles and purposes of these theories is Mathiesen's claim that "panopticism and synopticism have developed in intimate interaction, even fusion, with each other" (223). Viewing these two power structures as one functioning unit distorts the perception of who holds the power. Thus, a simple critique of synopticism is that while individuals possess some authority, "it is very much a double-sided coin: the internet also opens up profound new opportunities for surveillance" (Doyle 294). Rather than support Mathiesen's claim that panopticism and synopticism are fused, evidence points to a new adaptation of the Virtual Panopticon - the production of synopticism. This intentional product of panopticism is used to keep inmates chained yet comfortable in their virtual cells, and anyone with access to technology such as laptops, televisions, and cellphones, those in power-social media platform owners, corporations, online businesses, etc.- create an illusion of freedom.
Synopticism relies on many viewing the few; however, regarding technology, especially social media, personal usage is just as much an individual endeavor as a communal experience. Initially, posting on social media appears to support synoptic theories, but consider that the decision and actions needed to post are dependent on one person. One might even say they are isolating. The individual posting subjects themself to others' gaze while feeling in control. This sense of control prevents the individual from perceiving the invasive and judgmental panoptic eye. There remains the looming power of the platform owners, algorithms, etc. Does an individual posting on social media give them more power than the platform itself? Scholars note that Mathiesen "only briefly discussed how the panopticon and synopticon actually interact and mutually reinforce one another" (Doyle 296). Illusory synopticism is the first attempt to bridge this gap in Mathiesen's research since "across [these] literatures, the synopticon notion has been taken up largely uncritically" (Doyle 287). The following sections outline a new term, illusory synopticism, and explain how the Synoptic functions within the Panoptic rather than supporting the view of the Panopticon and Synopticon as one fused structure.

\section{Illusory Synopticism}

Illusory synopticism thrives off humans' innate desire to know, thus making the illusion of omniscience appealing. One effect of virtual panopticism is the idea that "we have conditioned ourselves into thinking we can't do anything or make any decisions without constantly being in the know" (Morris 19). To create an accurate perception of power that is gained through knowledge using panoptic and synoptic structures, individuals must first understand how and what information is passed between these systems. Mathiesen reveals the primary content of this information in conjunction with a small summary of how news travels between the Synopticon and the Panopticon, "news from these parts of panopticon-news about prisoners, escapes, robberies, murder - are the best pieces of news which synopticon-television and the tabloid papers - can find" (231). Mathiesen's analysis remains both accurate and relevant, and the daily proof is evident from the morning news to YouTube; headlines consist of gruesome stories which seep into the community as readers, watchers, and listeners all participate in this cycle. While Mathiesen's claim is true-news in 
the Panoptic and Synoptic travels through tabloids and television - a modern-day addition of cellphones usage must also be considered. Additionally, Mathiesen fails to state explicitly one key fact: humans do not resist the temptation to gain knowledge. While Mathiesen implies this fact, he limits the potential ways in which technology influences users. For example, gaining knowledge from online sources ranges from social media posts to news outlets to gossip columns to online university programs. Mathiesen's narrow approach discounts the reality of deep technological integration. The Information Age marks the time in history in which technological integration promotes learning faster than ever before. Of course, not all people can access the internet or purchase technological devices, which Mathiesen notes, remarking, "the Internet and the Web are hardly for "everyone" (224). Despite inaccessibility for all, Mathiesen claims that users who can access technology possess great power. However, he fails to consider that "people are not simply blank slates on which the synoptic media impose a message" (Doyle 293). The combination of previous knowledge with the addition of synoptic media creates a setting in which those with access to technology feel secure because their device provides them with immediate answers. Within this safe place, those in the Synopticon function as Mathiesen laid out above: they consume and reiterate news. After a while, users begin to feel omniscient even though they heavily depend on a blend of technology, memories, and experiences.

How much power is too much power? In a Synopticon, the power rests on the "many" who control the "few" (Mathiesen 215). Mathiesen's research claims that the increasing integration of technology into everyday life provides individuals with power, he writes, "indeed, great power-is located in concrete individuals and concrete delimited groups as represented in our mass media" (Mathiesen 226). His argument thrives off individual power, indeed seemingly unlimited omnipotent power. In contrast, Foucault's Panopticon "automatizes and disindividualizes power" (Foucault 202). Foucault expands on the idea of power within the Panopticon claiming that "power has its principle not so much in a person as in a certain concerted distribution of bodies, surfaces, lights, gazes." In other words, the "internal mechanism[s] produce the relation in which individuals are caught up" (Foucault 202). However, a tension arises between Mathiesen's heavy emphasis on individual power and the need for approval; "we do not want to be exposed, whether online or in person, unless we approve it" (Sheldahl-Thomason 238). Technological applications and devices such as social media and security cameras provide two examples of how little control an individual has over their own image in conjunction with technology. Mathiesen fails to mention the importance of who controls information in the virtual realm. His emphasis on individual power neglects the fact that the ultimate power resides with those who control data or create platforms. For example, app creators/ owners can decide to censor content, police can access security footage, and algorithms can be altered. These examples demonstrate that true power does not belong to users despite initial appearances. Even though true omnipotent power does not belong to users in the virtual realm, users - and even Mathiesen - accept the idea that they maintain power. Mathiesen's own belief in the significant power of users in technology is evidence that people are tricked into believing they maintain power, a key difference between a synoptical and panoptical approach.

The illusion of omnipresent power is directly tied to the mobility of technology. Cellphones, laptops, and tablets are all examples of how technology can travel with users. Easy transportation aids in further technological integration because it allows users to access platforms effortlessly and conveniently. With the feeling of omnipresent power comes a concerning truth: "the power of visible and concrete rulers was and is fading away" (Mathiesen 226). Mathiesen recognizes his opinion aligns with Foucault's idea that "the visible actors' power in central institutions of state and society is blurred" (Mathiesen 226). Both Foucault and Mathiesen recognize that the person/people in power are harder to identify because power is less focused on outward dominance as compared to internal control. If users cannot identify who is in control, then they most assuredly cannot locate where the leader lives (in the virtual realm). The virtual world only furthers Foucault and Mathiesen's claims. The inability to know who is in control is concerning because users are constantly exposed to these controllers' decisions. Exposure draws attention to the inherent hierarchy laid out by Foucault - "the exposure of the modern subject to judgement drives the modern subject to expose herself to a set of societal values and to live those values in her life" (Sheldahl-Thomason 233). The exposer maintains more power than the exposed. How can users protect 
themselves when they are unaware of who can see them? Users are unaware of who holds power over them in the virtual realm because they have bought into illusory synopticism, which grants them feelings of omnipotence, omniscience, and omnipresence. These illusions are dangerous and demand immediate attention.

Further research is pointless if there is no distinction between a fused Virtual Panopticon/Synopticon and a Virtual Panopticon which produces illusory synopticism. Mathiesen's fusion of the Panopticon and Synopticon misplaces power; his theories blur the line between the inmates and the guards claiming that the "panopticon and synopticon reciprocally feed on each other" (231). He claims "the most typical medium where the many see the few, the clearest contrast to Foucault's panopticism, has in other words developed dramatically, either directly or through its influence on the older media" (221). Since panopticism precedes synopticism, far more research exists on the Panopticon than on the two theories combined; however, the dynamic between the Panoptic and Synoptic needs to be clearly defined. Foucault's theories of bureaucracy — "a new white-collar force [that] is necessary to set up the procedures for information retrieval and storage"-and specialization - "[where] members of the workforce are organized into increasingly specialized fields, so much so that we increasingly rely on other 'experts' to complete tasks that had previously been shared or common knowledge" - are critical to a successful Panopticon (Felluga). People must produce. The producers become more valuable than the common inmate. In a Virtual Panopticon, illusory synopticism becomes the means through which inmates produce and therefore increase in value. A cellphone acts as a window, allowing the inamte to see the world from certain angles. However, platforms such as social media do not remove the isolating effects that the Panoptic must maintain in order to function. Social media cannot replace human-to-human interactions; this is why users can have social media accounts yet still feel lonely. The incorporation of technology, even when designed for social engagement, does not guarantee community or friendships. However, technology allows inmates enough freedom to feel comfortable in their cells. Synopticism as a product of panopticism creates an environment in which the cell doors of Virtual Panopticons could open, and yet individuals would stay put. However, what users fail to recognize is that the Panopticon is not a free place to live. Due to its "laboratory of power," a
Panopticon affects behavior (Foucault 204). Relying on observation, the Panopticon is structured "to penetrate into man's behavior; knowledge follows the advances of power, discovering new objects of knowledge over all the surfaces on which power is exercised" (Foucault 204). With users' attention diverted by technology, the Virtual Panopticon continues to grow in strength and numbers. One alternative to succumbing to Virtual Panopticons is to avoid technology (social media, online shopping, etc.). However, setting devices aside may be more challenging than in the past, considering that " $97 \%$ of Americans now own a cellphone of some kind" and " $72 \%$ of the public uses some type of social media" (Pew Research). While it is not impossible to break out of a Virtual Panopticon, it is difficult and made increasingly more challenging with the added layer of illusory synopticism. Thus, the Panopticon reinforces its walls with deception.

\section{Conclusion: Signs of Technological Dependency}

The surest way to teach a concept is by providing relevant examples. How are Virtual Panopticons and illusory synopticism manifesting in everyday life? Consider this statistic: "According to recent research from dscout, people tap, swipe, and click an average of 2,617 times per day" (Cell Phone Addiction). If an individual does anything over 2,500 times a day, it will influence their life. The jarring effects of this statistic continue when you apply Foucault's philosophical lens to the issue: " The Panopticon] programmes, at the level of an elementary and easily transferable mechanism, the basic functioning of a society penetrated through and through with disciplinary mechanism" (209). A Virtual Panopticon is easier to fall into than ever before. If individuals have access to the internet and/or social media, they are involved in a Virtual Panopticon. Within this system, users are encouraged to remain inside the Panopticon via feelings of security and comfort - that is, via illusory synopticism, which manifests in technological dependency. As stated in the prior section, a cellphone allows users to feel omniscient, omnipotent, and omnipresent. The human desire for security and power is so strong that even the idea of these three qualities is preferable to reality. Here we see the Synoptic operating within the cells of the Panoptic. Further research could extend into each inmate's use of the illusory synoptic (i.e., social media), and new studies could be conducted to see if 
each user runs their social media account similar to a Panopticon, which would line up with Foucault's theories of internalizing the panoptic rule in each person's life. Due to time constraints, this research must be left for a later date.

Technological dependency or addiction reaches beyond physical effects such as the number of times a person touches their phone and into emotional and mental realms. Research continues to expand as the use of technology continues to rise. In fact, "the number of users is increasing significantly with more than 1.08 billion users around the world in 2012" (Mi Shin 29-30). While connecting technology to mental health challenges began as speculation, researchers have found "evidence to support that there is a correlation between negative emotion and mobile phone addiction levels [that] has been rapidly accumulated in recent years" in children and adolescents (Mi Shin 33). Defining negative emotions as "the evocation of one's unpleasantness or unhappiness, with negativity expressed as depression, anxiety, loneliness, and anger" highlights the importance of immediate action (Mi Shin 33). Technology is not a passively existing network; technology is affecting reality to the point of changing humans' minds. Further statistics reveal that "Americans spend an average of 5 hours per day browsing" (Cell Phone Addiction). Put differently, nearly 21\% of each day is spent engaging with technology. Though this work highlights a plethora of adaptations of Foucault's Panopticon to the virtual realm, the impressive rate at which technology is advancing puts researchers at a disadvantage. Computers don't need sleep, and algorithms never tire. Researchers must remain vigilant in the face of a formidable opponent. The question then becomes, what good is research if it is outdated by the time it is published? Perhaps the documentation of technological trends and patterns is important because it allows users to speculate where they're headed next. Documentation also aids researchers in determining what succeeded and what failed. Research grants humans the opportunity to learn from history.

The effects of using social media are a mixture of eerie warnings and positive advancements that, when combined with the wide influence of the internet, leave researchers working to understand what is going on in the virtual world. Social media can have a positive effect on users despite its panoptic structure and illusory synoptic product. For example, a survey was conducted with a group of cancer patients who used social me- dia to combat depression, and researchers found "that the users of the social network are less depressed; this finding confirms other researchers' evidence that social networks can have a positive influence on health and improve health outcomes for people with depression" (Farpour, Hamid Reza, et al. 2987). The specificity of this survey is important to note. Because social media affects users individually, it is reasonable to conclude that a different person who uses social media may have a different outcome. Further research shows that those "who share a common language or viewpoint" about the importance of connection to sustain life "would most likely use social media in socially useful ways.". In contrast, "individuals who do not hold this belief about connection with others and/or who may possibly use social media as a way to act in self-serving or harmful ways toward others" (Belangee, et al. 131). To assume that all social media is corrupt is to overlook positive contributions to individual lives and society. However, users must decide how best to use social media for themselves, and a deeper understanding of the Panoptic and of illusory synopticism may aid in their decision making.

How can individuals break free from the toxic cycles of virtual panopticism? First, users must identify if there is a problem. Cellphone addiction can look like reaching for the phone first thing in the morning, using cellphones when bored, becoming anxious or agitated when the cellphone is out of sight, people around them complaining about their cellphone use, and the inability to cut back on cellphone usage (Cell Phone Addiction). According to research completed on children and adolescents, problems such as vehicle crashes, musculoskeletal disorders, eye disorders, electromagnetic radiation, infection, mental health, social relationships, and academic achievement and functioning may occur due to cellphone addiction (Mi Shin 36-39). To avoid completely surrendering to the powers of virtual panopticism and illusory synopticism, taking breaks from technology - and specifically social media - is vital. Willingly walking out of the Virtual Panopticon reveals an awareness that greater forces are at work. By choosing to resist virtual panopticism, even for a short time, users remember that they are not required to subject themselves to these systems. Small actions, such as an individual decision to step outside the Virtual Panopticon for a set amount of time to think, will begin to shed light on the corruption of the structures in 
place. Mathiesen claims that "taken as a whole, things are much worse than Michel Foucault imagined" (231). The enablement of technology allows structures to adapt in forms researchers have never witnessed before. As these new structures are built, people must remain hopeful that change can happen. Individuals must fight for ethical parameters in the virtual realm, or Virtual Panopticons will enslave all who engage in using the internet. As awareness spreads, individuals must remain hopeful that actions will follow. Perhaps Mathiesen could see what was to come when he wrote, "to muster such double resistance is a difficult task...in the years to come, much effort and lots of time should therefore be devoted to the search for the roads to resistance" (231).

\section{Work Cited}

Behrent, Michael C. "Foucault and Technology." History \& Technology, vol. 29, no. 1, 2013, pp. 54-104. Routledge Taylor and Francis Group, doi: $\underline{10.1080 / 0}$ 7341512.2013.780351.

Belangee, Susan, et al. "Cybersocial Connectedness: A Survey of Perceived Benefits and Disadvantages of Social Media Use." Journal of Individual Psychology, vol. 71, no. 2, University of Texas Press, Summer 2015, pp. 122-34.

Bentham, Jeremy. Correspondence of Jeremy Bentham, Vol. 1: 1752 to 1776. Edited by Timothy L. S. Sprigge, UCL Press, 2017. JSTOR, www.jstor.org/stable/j. ctt1qnw8c9. Accessed 9 Feb. 2021.

Brunon-Ernst, Anne. Beyond Foucault: New Perspectives on Bentham's Panopticon. 2012, Routledge Taylor and Francis Group.

Campbell, John and Matt Carlson. "Panopticon.Com: Online Surveillance and the Commodification of Privacy." Journal of Broadcasting \& Electronic Media, vol. 46, no. 4, 2002, Broadcast Education Association, p. 586. doi:10.1207/s15506878jobem4604_6.

Cayford, Michelle, and Wolter Pieters. "The Effectiveness of Surveillance Technology: What Intelligence Officials Are Saying." Information Society, vol. 34, no. 2, 2018, Routledge Taylor \& Francis Group, pp. 88-103. doi:10.1080/01972243.2017.1414721.

"Cell Phone Addiction: Stats and Signs." King University Online, https://online.king.edu/news/cell-phone-addiction/. Accessed 25 Mar. 2021.
Couch, Danielle L., et al. "COVID-19-Extending Surveillance and the Panopticon." Journal of Bioethical Inquiry, vol. 17, no. 4, Dec. 2020, pp. 809-14. Springer Link, doi:10.1007/s11673-020-10036-5.

"Demographics of Mobile Device Ownership and Adoption in the United States." Pew Research Center: Internet, Science \& Tech, https://www.pewresearch. org/internet/fact-sheet/mobile/. Accessed 7 Aug. 2021.---. "Demographics of Social Media Users and Adoption in the United States." Pew Research Center: Internet, Science \& Tech, https://www.pewresearch.org/internet/fact-sheet/social-media/. Accessed 7 Aug. 2021.

Doyle, Aaron. "Revisiting the Synopticon: Reconsidering Mathiesen's 'The Viewer Society' in the age of Web 2.0." Theoretical Criminology, 2011, pp. 283-299. Sage Publication, doi: 10.1177/13624806 10396645.

D'Urso, Scott C. "Who's Watching Us at Work? Toward a Structural-Perceptual Model of Electronic Monitoring and Surveillance in Organizations." Communication Theory (1050-3293), vol. 16, no. 3, 2006, International Communication Association, pp. 281303. doi:10.1111/j.1468-2885.2006.00271.x.

Farpour, Hamid Reza, et al. "Positive Impact of Social Media Use on Depression in Cancer Patients." Asian Pacific Journal of Cancer Prevention : APJCP, vol. 18, no. 11, 2017, pp. 2985-88. PubMed Central, https://doi.org/10.22034/APJCP.2017.18.11.2985.

Felluga, Dino. "Modules on Foucault: On Panoptic and Carceral Society." Introductory Guide to Critical Theory. 2011, Purdue U. http://www.purdue.edu/ guidetotheory/newhistoricism/modules/foucaultcarceral.html.

Felluga, Dino. "Modules on Foucault: Power." Introductory Guide to Critical Theory. 2011, Purdue U.

https://www.cla.purdue.edu/academic/english/theory/ newhistoricism/modules/foucaultpower.html

Foucault, Michel, Discipline and Punish: The Birth of the Prison. New York: Pantheon Books, 1977.

Gutting, Gary and Johanna Oksala, "Michel Foucault," The Stanford Encyclopedia of Philosophy (Spring 2019 Edition), Edward N. Zalta (ed.), <https://plato. standford.edu/archives/spr2019/entries/foucault/>.

Internet Growth Statistics 1995 to 2021 - the Global Village Online. https://www.internetworldstats.com/ emarketing.htm. Accessed 5 Aug. 2021. 
Manokha, Ivan. "Surveillance, Panopticism, and Self-Discipline in the Digital Age." Surveillance \& Society, vol. 16, no. 2, 2018, Open Journal System, pp. 219-37. doi:10.24908/ss.v16i2.8346.

Martin, Glen. "The Digital Panopticon." Utne, no. 202, Ogden Publications, Inc., Spring 2019, pp. 70-72.

Mathiesen, Thomas. "The Viewer Society Michel Foucault's 'Panopticon' Revisited." Vol. 1(2), Sage Publications, 1997, pp. 215-234.

Mi Shin, Yun. "Smartphone Addiction in Children and Adolescents." Internet Addiction in Children and Adolescents: Risk Factors, Assessment, and Treatment. Springer Publishing Company, 2017, pp. 2945.

Miller, Jacques-Alain, and Richard Miller. "Jeremy Bentham's Panoptic Device." October, vol. 41, The MIT Press, 1987, pp. 3-29. JSTOR, doi:10.2307/778327.

Morris, Williesha. "Technology Addiction." OfficePro, vol. 74, no. 6, International Association of Administrative Professionals, Oct. 2014, pp. 14-17.

Panopticon | Origin and Meaning of Panopticon by Online Etymology Dictionary. https://www.etymonline.com/word/panopticon. Accessed 6 Apr. 2021.

Paternek, Margaret A. "Norms and Normalization: Michel Foucault's Overextended Panoptic Machine." Human Studies, vol. 10, no. 1, 1987, pp. 97-121.JSTOR, www. jstor.org/stable/20008990. Accessed 10 Feb. 2021.

Pickett, Brent L. "Foucault and the Politics of Resistance." Polity, vol. 28, no. 4, 1996, The University of Chicago Press, pp. 445-466. www.jstor.org/stable/3235341. Accessed 2 Feb. 2020.

Piro, Joseph M. "Foucault and the Architecture of Surveillance: Creating Regimes of Power in Schools, Shrines, and Society." Educational Studies, vol. 44, no. 1, Taylor \& Francis Ltd, Aug. 2008, pp. 30-46. EBSCOhost, doi:10.1080/00131940802225036.

Poster, Mark. "Foucault, the Present and History." Cultural Critique, no. 8, 1987, pp. 105-121. JSTOR, www.jstor.org/stable/1354213. Accessed 10 Feb. 2021.

Presswood, Alane. "Avowal Is Not Enough: Foucault and Public Shaming in a Socially Mediated World." Ohio Communication Journal, vol. 55, 2017, Ohio Communication Association, pp. 43-53.

Richards, Neil M. "The Dangers of Surveillance." Harvard Law Review, vol. 126, no. 7, 2013, pp. 1934 1965. JSTOR, www.jstor.org/stable/23415062. Accessed 10 Feb. 2021.
Sheldahl-Thomason, Strand. "Foucault and the Use of Exposure: Discipline, Ethics, and Self-Writing." Review of Communication, vol. 19, no. 3, July 2019, pp. 225-40. Routledge Taylor and Francis Group, doi:10.1080/15358593.2019.1635710. 